\section{Journal of Energy \&. \\ Environmental Sciences}

Vol. 5, $\mathrm{N}^{\circ}$ 1, 2021

\title{
Influence of the plastic law on the consumption of Biodegradable containers in the Peruvian Population [Educación Influencia de la ley de plásticos en el consumo de envases biodegradables en la población peruana]
}

\author{
Flor Angélica Lavanda Reyes (iDa, ${ }^{*}$ \\ aUniversidad Nacional San Luis Gonzaga, Ica, Perú \\ *flavanda@unica.edu.pe
}

Received: 16 April 2021; Accepted: 30 April 2021; Published: 05 May 2021

\begin{abstract}
Resumen
La contaminación es un fenómeno que se presenta en todos los países del planeta, lo que lleva a diseñar estrategias para mitigarla; el Perú no es ajeno a ello y genera más se siete millones y medio de toneladas de residuos sólidos al año, de donde el $64 \%$ proviene de hogares y el consumo al año promedio por ciudadano es de 30 kilos de plástico. Situación preocupante que llevó al gobierno a la aprobación de la Ley №30884 denominada Ley que Regula el Plástico de un solo uso y los Recipientes o Envases descartables. Se planteó el problema: ¿De qué manera la aplicación de la Ley de Plásticos influye en el consumo de envases biodegradables en la población? Para este estudio se aplicó una encuesta a una muestra representativa formada por consumidores elegidos aleatoriamente en diversas zonas del país. Los resultados muestran que a pesar de haberse realizado campañas y estrategias para concientizar a dejar el uso de bolsas plásticas y envases de tecnopor, no se presentan cambios relevantes en el comportamiento de los consumidores
\end{abstract}

Palabras clave: Contaminación, Ley de Plástico, envases biodegradables, reciclaje

\begin{abstract}
The pollution is a phenomenon that occurs in every country on the planet, which leads to design strategies to mitigate it. Peru is no stranger to this and generates more than seven and a half million tons of solid waste per year, from which $64 \%$ comes from households and the average annual consumption per citizen is $30 \mathrm{~kg}$ of plastic. Worrying situation that led the government to approve Law N 30884 called Law that Regulates Single-use Plastic and Disposable Containers or Containers. The problem was raised: How does the application of the Plastic Law influence the consumption of biodegradable packaging in the population? For this study, a survey was applied to a representative sample made up of randomly chosen consumers in various areas of the country. The results show that despite having carried out campaigns and strategies to stop using plastic bags and tecnopor containers, there are no relevant changes in consumer behavior.
\end{abstract}

Keywords: Pollution, Plastic Law, biodegradable packaging, recycling.

\section{Introduction}

In recent years, caring for the environment has become a topic of interest to researchers from various disciplines, seeking to mitigate the reported rates of solid waste and the consequences that this causes on public health. 


\section{Journal of Energy \& Environmental Sciences}

Vol. 5, $\mathrm{N}^{\circ} 1,2021$

Copyright @ 2021, CINCADER.

ISSN 2523-0905

DOI: https://doi.org/10.32829/eesj.v5i1.223

An analysis has been carried out on the behavior of the Peruvian population, finding that only 3 out of 100 Peruvians recycle the garbage they generate daily. This shows that there is no recycling culture formed in the citizenry, where people mix various types of waste and deliver it to garbage collection trucks. This situation is aggravated in cities further away from the capital, where the population is less aware of recycling and due to lack of interest or lack of information it is easier to dispose of products that could not be reused. Another problem is the deficient garbage collection system and the lack of collection centers and orientation of the bins in various areas of the cities or institutions where it is not indicated by colors or names what type of waste (such as: glass, paper, plastic, etc.), must be placed for a correct separation of solid waste.

Given the increase in the use of plastic and the environmental pollution that this generates, alternatives that had been applied in other countries of the region with favorable results were analyzed, such as Colombia that incorporated a tax on the use of plastic bags and Chile that banned bags plastic in their establishments. At the country level, there were also positive experiences such as the District Municipality of La Molina - Lima, which through Ordinance No. 324-2016 promotes the reduction of the use of items made from plastic and single-use in your district. In order to reduce the use of plastic bags and promote the use of biodegradable products throughout the country, the Peruvian government approved Law No. 30884 on 12/08/2018. Therefore, the problem arises, What way does the application of the Plastics Law influence the consumption of biodegradable packaging in the population in? And the objective, to identify the level of influence of the law in favor of the biodegradable packaging consumption in the population.

\subsection{Law regulating single-use plastic and disposable containers or containers}

Law No. 30884 published in the Newsletter El Peruano on December 19, 2018, regulates singleuse plastic and disposable containers or containers. In its Article 1: object and purpose of the law, it states that the purpose of the law is to establish the regulatory framework on single-use plastic, other non-reusable plastics and containers or disposable expanded polystyrene (tecnopor) containers for food and drinks for human consumption in the national territory.

The purpose of the law is to contribute to the realization of the right that every person has to enjoy a balanced and adequate environment for the development of his life, reducing the adverse impact of single-use plastic, plastic marine litter, river and lake and other similar pollutants, in human health and the environment.

In Article 3: Prohibition of single-use plastic and disposable containers or containers, regulates the manufacture, import, distribution and consumption of single-use (or disposable) plastic, such as bags, straws, tecnopor, among others to protect the environment and health from the contamination generated by the residues left by these products. It establishes the deadlines for said products to remain on the market and their gradual exit from it, the competent entities in their application and control, in such a way that there is a process of adaptation in the changes of use and the buying behavior of consumers towards biodegradable products.

In Article 7: Citizen education and environmental commitment, through the Ministry of the Environment, the Ministry of Education, the Ministry of Production and decentralized governments contemplate citizen education actions, where the participation and awareness of the population in actions for the care of the environment is promoted, such as the dissemination of July 3th of each year as the International Free Day of Plastic Bags, and Wednesday is declared as Plastic Recycling Day, actions that must be shared and develop an environmental commitment in the population, actions like these promote the increase of the green consumer, which is that person concerned about caring of the environment and its purchasing and consumption actions seeks products that do not harm or pollute, acquiring biodegradable or recycled products. 
Vol. 5, $\mathrm{N}^{\circ} 1,2021$

EES

\section{Journal of Energy \&. Environmental Sciences}

Copyright @ 2021, CINCADER.

ISSN 2523-0905

DOI: https://doi.org/10.32829/eesj.v5i1.223
A publication of

CINCADER

Centre of Research and Training for

Regional Development

Online at www.journals.cincader.org

In Article 12: Consumption Tax on plastic bags, it establishes a payment in soles money for each type of bag that we buy in an establishment, which will be 0.10 cents in 2019, 0.20 cents in 2020, 0.30 cents in 2021, 0.40 cents in 2022 and 0.50 cents for 2023 and the following years, we find that consumers do not agree with the tax, the problem is that consumers do not become familiar still with this practice of carrying reusable bags, so a greater offer of biodegradable packaging on the market would be desirable.

\subsection{Biodegradable packaging}

According to Phillip Kotler (2017), the container is that wrapping or container that protects the product, allowing the distribution and conservation of the product, in such a way that it retains its own characteristics until it reaches the hands of consumers.

According to Fisher and Espejo (2004), packaging is defined as any material that encloses an item with or without packaging, in order to preserve it and facilitate its delivery to the consumer. For many, the first emotional impact on the consumer is given by the packaging.

Biodegradable packaging is those that naturally degrade quickly when discarded and have a low impact on the environment. In the most industrialized countries, packaging is one of the most important parts of the garbage, because a plastic bag, no matter how biodegradable, takes years to disappear, that is, it takes 150 years to do so, compared to a $100 \%$ biodegradable (not all are), which begins its degradation process at 18 months That is why they usually have a manufacturing or printed date.

According to the Center for the Conservation of Energy and the Environment (CENERGIA), the raw materials for the production of biodegradable plastic containers are:

- Banana peels

- Potato peels

- Corn

- Tomato skin

- Silk and Shrimp

- Mushrooms

According to Ruiz, G., Montoya, C. \& Paniagua, M. (2009) different ways have been created to create plastic bags with polymers, which makes them biodegradable plastics, making them friendly to the environment. Studies have been carried out on the degradation of these cassava starch-based bags, which show a salvation for environmental pollution, since they fulfill their function and become degraded in recommended times and under natural effects such as the sanitary landfill, salt water or sweet and sunlight.

According to Jesús Israel Zárate Gómez (2014), bioplastic is also one of the many options that are being created in order to have a lesser impact on the environment, the interesting thing is that it is manufactured from renewable sources, some made from corn and corn. its impact is beneficial, since its decomposition is faster when it is directly related to water.

According to Raúl Postigo Márquez (2017), plant fiber, such as wheat husk or straw, rice, bamboo, palm leaf, corn starch, among others, is used as alternatives for the production of packaging at a lower cost. and the distribution of them with greater benefits for consumers. It must be taken into account that the use of tecnopor containers is the most consumed by food companies, restaurants and cafeterias for the delivery of prepared foods, as well as fruits and vegetables.

\subsection{Recycling}

According to Coreaga (1993), the recycling process is an activity that involves the use of energy to obtain new products in a recycling plant. 


\section{Journal of Energy \&. Environmental Sciences}

Vol. 5, $\mathrm{N}^{\circ} 1,2021$

Copyright @ 2021, CINCADER.

ISSN 2523-0905

DOI: https://doi.org/10.32829/eesj.v5i1.223

According to Wathern (1988), recycling is a set of actions carried out by nature and man on different materials to recover and use them again.

According to Ramos (2010), the importance of recycling implies and entails a series of processes and industrial-type processes, starting from wastes and residues, resulting in obtaining a series of materials or substances that are reintroduced into the production process.

From the analysis of plastic recycling, Virginie (2011), affirms that $90 \%$ of plastic can be recycled, however its diversity in terms of composition and use makes collection and classification difficult. A sensitive issue in plastics is the bottles that of the 12,000 that are consumed per minute, we found that only $36 \%$ that enter the market are reused, because they are recovered by recyclers who look for them in garbage cans because they can sell them. The concern is that each plastic has a specific recycling process, for example: PET bottles take the longest to degrade.

From the business perspective, it is necessary to guide the population on their purchase and consumption actions, presenting entrepreneurial opportunities for new green businesses that generate considerable economic income and that constitute an alternative for consumers and companies that require eco-friendly products. In Peru we have entrepreneurs dedicated to recycling, for example: Empresa Bolsos Ecológicos del Perú, which has been in the market for 7 years, dedicated to the transformation of plastic bottles into fibers and fabrics, with which they make advertising bags, make flowerpots. ecological, notebooks, backpacks and jackets by recycling plastic.

\section{Materials and Methods}

In the research, the specific design used was longitudinal. A basic research was carried out with the objective - subjective method, it was developed between July 2019 and June 2020, considering three stages: first, a study project was prepared in which a situational analysis of the Peruvian market was made, between the months of July and September 2019 finding high rates of pollution and plastic consumption in various cities, being Lima, Ica and the high Andean cities of Peru those that report the highest rates of solid waste. Second, a secondary information survey was carried out between October 2019 and January 2020, going to institutions such as Municipalities, National Institute of Statistics and Informatics, Ministry of the Environment, among others. For primary information, the study population was considered to be consumers from the departments of Lima, Ica and La Libertad, the study sample was made up of consumers between 18 and 70 years of age, considering a total of 384 people, from Lima, Cañete, Trujillo, Ica, Pisco and Chincha. The field work was carried out between January and March 2020. Third, the analysis and interpretation of the results was carried out for the formulation of the conclusions and recommendations between the months of April and June 2020.

The applied technique was observation, using a checklist, it was applied in different areas of the city, being able to observe that consumers leave garbage in the streets, food waste in parks and there are no colored bins for solid waste. A survey was applied between January 27 and February 10,2020 in different areas of the city and online to the 384 consumers in the study sample, using a questionnaire of 10 open, closed and multiple-choice questions. Structured interviews were also conducted with the authorities of 6 municipalities, in the area of environmental development and parks and gardens, on the problem of pollution and the treatment they give to solid waste. 


\section{Journal of Energy \&. Environmental Sciences}

Vol. 5, $\mathrm{N}^{\circ}$ 1, 2021

\section{Results}

The sample was structured and made up of 384 consumers, made up of the following:

Table 1. Study sample

\begin{tabular}{lccc}
\hline Gender & $\begin{array}{c}\text { Between } 18 \text { and } \\
35 \text { years old }\end{array}$ & $\begin{array}{c}\text { Between } 36 \text { and } \\
50 \text { years old }\end{array}$ & $\begin{array}{c}\text { Between } 51 \text { and } 70 \\
\text { years old }\end{array}$ \\
\hline Male & 74 & 62 & 57 \\
Female & 66 & 72 & 43 \\
\hline Total & 140 & 144 & 100 \\
\hline
\end{tabular}

The study sample was made up considering the criteria of gender and age, because consumer behavior changes depending on these variables. If we analyze women between 18 and 35 years old, they are in an independent economic and social stage, their consumption is higher in singleuse products, such as food, so they buy more bags. Men in this age range seek practicality when acquiring products, so they are not interested in the type or material of the container, they do not show interest in carrying biodegradable bags, so their consumption of plastic is very high.

Women between 36 and 50 years old, a high percentage work and are housewives, so they buy a greater quantity of food and products, whose tecnopor and plastic containers are more practical to acquire. As for the men in this age range, they are parents and do household purchases, such as food, drinks, etc. They work and have work and social meetings, which lead to buying fast food, so their consumption of plastic and tecnopor containers is high.

Women between 51 and 70 years old, have a great responsibility for the environment, so they worry about carrying biodegradable bags, they check the labels of the containers to know the material. Men between 51 and 70 years of age also decrease their consumption of plastic bags, because their family activities in many cases increase so they are pending to acquire the products they only require and also show greater responsibility to separate solid waste by type.

Table 2. Frequency of caring for the environment

\begin{tabular}{lcc}
\hline & Frequency & $\%$ \\
\hline Always & 19 & 5 \\
Usually & 58 & 15 \\
Regularly & 261 & 68 \\
Seldom & 46 & 12 \\
Never & 0 & 0 \\
\hline Total & 384 & $\mathbf{1 0 0}$ \\
\hline
\end{tabular}

$68 \%$ of respondents expressed that they regularly take care of the environment, considering that they still throw waste on the streets, beaches, buy plastic bags, etc. despite being aware that they pollute seas, lakes, as well as water and air, which affects everyone. It is also important to consider that $5 \%$ expressed that they always take care of it, this is favorable because the population can change their consumption habits, to the extent that products with alternative packaging are offered in the market. 


\section{Journal of Energy \& Environmental Sciences}

Vol. 5, $\mathrm{N}^{\circ}$ 1, 2021

Table 3. Knowledge about Peruvian Plastic Law

\begin{tabular}{lcr}
\hline & Frequency & $\%$ \\
\hline Yes & 69 & 18 \\
No & 315 & 82 \\
\hline Total & 384 & 100 \\
\hline
\end{tabular}

The Plastic Law No. 30884 has been in force since December 2018 and various institutions carried out dissemination campaigns to make it known, using mass media and regional and local governments at the national level, as well as entities such as schools, universities, etc. they assumed the role of raising awareness among children and young people so that they could have a multiplier effect in their homes; However, $82 \%$ of those surveyed expressed not knowing that Peru had a law and its important points, only related to plastic bags and straws, products that they and their children accept to consume with great demand.

On the other hand, $18 \%$ of consumers express knowing about the law, but a striking aspect is not agreeing with its content, especially in payments for plastic bags and the deadlines established to stop using them, being Peru the last country in Latin America to approve it.

It is important to highlight that the Ministry of the Environment carries out actions constantly and with great responsibility the task of disseminating and enforcing the aforementioned law.

Table 4. Current use of plastic bags

\begin{tabular}{lcc}
\hline & Frequency & $\%$ \\
\hline Yes & 180 & 47 \\
No & 80 & 21 \\
Regularly & 124 & 32 \\
\hline Total & 384 & 100 \\
\hline
\end{tabular}

In 2017, Algalita Marine Research and Education discovered a list of plastics off the coasts of Chile and Peru. They estimated that it has an area of approximately 2.6 million square kilometers, almost twice the area of Peru. On average, approximately 30 kilos of plastic are used per year per citizen. Each year there are about 3 billion plastic bags, almost 6 thousand bags per minute. In Metropolitan Lima and Callao 886 tons of plastic waste are generated per day, representing $46 \%$ of said waste nationwide.

$47 \%$ of those surveyed express that if they use plastic bags, in some cases the old ones that they have stored, at this time because they seem stronger and safer than the current ones that are offered from other materials, as well as the ease of throw them away after use. On the other hand, because you prefer to pay to buy them in stores than to carry more than one bag in your wallet or briefcase.

$32 \%$ of respondents express that they regularly use plastic bags, which I think is remarkable, because they are taking responsibility in the use of said bags and that they are gradually ceasing to use them, mostly because they forgot to carry a reusable one or because you made a last minute purchase. 


\section{Journal of Energy \&. Environmental Sciences}

Vol. 5, $\mathrm{N}^{\circ}$ 1, 2021

Table 5. Frequency of use of plastic bags

\begin{tabular}{lcc}
\hline & Frequency & $\%$ \\
\hline Always & 61 & 16 \\
Usually & 104 & 27 \\
Regularly & 123 & 32 \\
Seldom & 88 & 23 \\
Never & 8 & 2 \\
\hline Total & 384 & 100 \\
\hline
\end{tabular}

According to Schiffman (2010), consumer behavior is defined as that which consumers show when searching, buying, using, evaluating and discarding the products and services that they consider will satisfy their needs. From this perspective, it can be identified that consumers have marked habits when carrying out their actions, so their repetitive actions require time to be overcome, especially if they have been carried out for long periods.

Peruvian consumers have used plain plastic bags, with designs for Mother's Day, Christmas, etc. for decades. This explains that $32 \%$ of those surveyed express that they regularly use plastic bags, that is, they are familiar with them and it is a natural action for them.

$27 \%$ of those surveyed expressed that they almost always use plastic bags, because consumers respond to practicality and convenience when it comes to transporting products of various types, we are still not familiar with the fact that the market no longer gives bags and we continue to go to establishments without them.

$16 \%$ of those surveyed expressed that they always use plastic bags, for sensitive products such as frozen foods, products that are going to have a single use, for waste of various types.

The analysis of these three alternatives leads us to consider that $75 \%$ of those surveyed continue to use plastic bags in their daily activities and that the dissemination strategies of the current law are not being adequate, because the results are small in their behavior.

Table 6. Knowledge of tax payment for the purchase of plastic bags

\begin{tabular}{lcc}
\hline & Frequency & $\%$ \\
\hline Yes & 93 & 24 \\
No & 291 & 76 \\
\hline Total & 384 & 100 \\
\hline
\end{tabular}

$76 \%$ of those surveyed do not know that they pay a tax when acquiring a plastic bag, that is, they express that it is incorrect to charge the bags in establishments when they were previously delivered free of charge, a situation that responds to compliance with the law. According to SUNAT, the tax they charge will be declared and paid on a monthly basis by the commercial and service establishments, for which I consider that it is necessary to provide informative talks, because the amount of the tax will be applied gradually until the year 2023. 


\section{Journal of Energy \& Environmental Sciences}

Vol. 5, $\mathrm{N}^{\circ}$ 1, 2021

Table 7. Opinion on biodegradable packaging

\begin{tabular}{lcc}
\hline & Frequency & $\%$ \\
\hline Very good & 98 & 25 \\
Good & 115 & 30 \\
Regular & 87 & 23 \\
Bad & 84 & 22 \\
\hline Total & 384 & 100 \\
\hline
\end{tabular}

The sum of the opinions (good, very good and fair) constitute $78 \%$ of consumers who demonstrate that they agree with the consumption of biodegradable packaging, which is very favorable for the market and for caring for the environment. According to Hamann (2014) Consumers are changing, we are more aware of what is happening to our planet, we look for products that do not pollute, that are friendly to the environment. This is expressed in changes in their purchasing and consumption behavior that leads us to have better opportunities in reducing plastic, for this it is a joint strategy between the companies that manufacture and those that demand these products. For example, the Qapac Runa Company, which in Spanish means "the one who has everything", its eco-friendly enterprise consists of a factory of disposable products made from sugar cane fiber. Among their products they have a salad bowl, round plates, glasses, etc. waterproof, resistant to liquids and oils and especially resistant to high temperatures, being able to be used in the microwave oven and heat your food. Salad bowl, round plates, glasses, etc. raincoats,

Table 8. Use of recycled products

\begin{tabular}{lcc}
\hline & Frequency & $\%$ \\
\hline Yes & 275 & 72 \\
No & 109 & 28 \\
\hline Total & 384 & 100 \\
\hline
\end{tabular}

$72 \%$ of those surveyed expressed that if they use recycled products at home, because they seem practical, original, they save money and generate work for many people, making it even more pleasant to buy them. It is also important to highlight that the $3 R$ format (Reduce, Recycle and Reuse) has had a motivating effect on the population, because it is familiar, pleasant and easy to remember for both young people and adults, generating motivation for better use. of the products. The National Quality Institute (INACAL), a body attached to the Ministry of Production, approved the Peruvian Technical Standard -NTP-ISO 18604: 2020, which describes the requirements for containers such as plastic bottles, glass, aluminum, etc. can be considered recoverable through the recycling of material, which leads to a responsible management of solid waste and to have a greater commercial interest in recycling products.

In recent years, the demand for recycled products has led many people to dedicate themselves to the business of buying and selling waste, because they take on a new useful life in the market. For example, the polar blankets that we use so much in the winter are recycled plastic bottles, with 40 bottles we can obtain a blanket, which is why its price is economical in the market and offers those who use it shelter for much longer. 


\section{Journal of Energy \& Environmental Sciences}

Vol. 5, $\mathrm{N}^{\circ} 1,2021$

Copyright @ 2021, CINCADER.

ISSN 2523-0905

DOI: https://doi.org/10.32829/eesj.v5i1.223

\section{Conclusions}

According to the results obtained by authors, it can be concluded that:

- This research concludes that the dissemination strategies applied so that Peruvians know the outstanding elements of the Plastics Law have not achieved the objective of raising awareness and achieving substantial changes in the purchasing and consumption behavior of the majority of inhabitants in various areas of the country. They recognize that they currently use plastic bags, tecnopor containers, among others considered prohibited.

- An outstanding aspect is the ignorance of consumers who pay a tax when buying a plastic bag; Due to the fact that this has a projection of an increase in the price to pay until the year 2023, the rejection reactions will be more frequent because they consider that their contribution does not have a favorable investment and the company is the one that benefits.

- In relation to biodegradable packaging, they are increasingly consumed by customers due to the varied designs with which they are offered, both the companies that manufacture them and the companies that acquire them have managed to increase their acceptance in a favorable way by consumers.

- Recycling is a commercial activity promoted by the authorities of various sectors, which has led to greater importance in consumer attitudes when separating solid waste and a greater result when transforming it into a new product.

\section{References}

Algalita Marine Research and Education. 2017. https://www.minam.gob.pe/menos-plastico-masvida/cifras-del-mundo-y-el-peru/

Coreaga, J. Manejo y Reciclaje de los Residuos de Envases y Embalajes. México C.D.: Instituto Nacional de Ecología. 1993.

Fisher, L y Espejo, J. Mercadotecnia México C.D.: Mc Graw Hill Iberoamericana. 2004.

Hamann, A. El Marketing Verde: Un Compromiso de todos. Lima: Editorial de la Universidad ESAN. 2014.

Kotler, P. Fundamentos del Marketing Madrid: Editorial Pearson Prentice Hall. 2017.

Ministerio del Ambiente. Reglamento de la Ley de Plástico. Decreto Supremo N 006-2019MINAM. 2019. en www.minam.gob.pe

Normas Legales. Ley N³0884 Ley que Regula el Plástico de Un Solo Uso y los Recipientes o Envases Descartables. Lima, Perú: Editorial del Diario Oficial El Peruano. 2018.

Norma Técnica Peruana-NTP-ISO

18604:2020

http://www.gob.pe/institucion/inacal/noticias/302385-inacal-aprueba-norma-técnicaperuana-para-reciclaje-de-envases

Postigo, R. Plan de Tesina titulado: Análisis y uso de productos alternativos a base de maíz y cáscara de arroz para el proceso de envases biodegradables.2019. https://repositorio.ucsp.edu.pe/bitstream/UCSP/16023/1/POSTIGO_MARQUEZ_RAU_M Al.pdf. Accessed March 16, 2020 


\section{Journal of Energy \&. Environmental Sciences}

Vol. 5, $\mathrm{N}^{\circ}$ 1, 2021

\section{CINCADER}

Centre of Research and Training for

Regional Development

Online at www.journals.cincader.org

Copyright @ 2021, CINCADER.

ISSN 2523-0905

DOI: https://doi.org/10.32829/eesj.v5i1.223

Ramos, R. El Reciclaje en la Sociedad Actual. Madrid: Wanceulen Edit. 2010.

Ruiz, G., Montoya, C.\& Paniagua, M. Degradabilidad de un Polímero de Almidón de Yuca. Revista EIA, (12), 67-68 2009.en www.scielo.org.co/pdf/eia/n12/n12a06.pdf. Accessed March 16, 2020

Schiffman, L, y Lazar, L. Comportamiento del Consumidor. México, C.D.: Editorial Pearson Educación. 2010.

Virginie, M. Los Caminos del Reciclaje. Madrid: Nuevos Emprendimientos Editoriales S.L. 2011.

Wathern, P. Ecological Evaluation Techniques, Landscape Planning. London: Biddles Ltd.1988.

Zárate J. Percepción del Consumidor ante la eliminación de bolsas plásticas en la Tienda por Departamento de Ripley Mall del sur, 2018 en https://www.usil.edu.pe/investigacionusil/repositorio-institucional. Accessed March 26, 2020. 